\title{
ANALISA INTERPRETASI POLA ALIRAN AIR BAWAH TANAHKELURAHAN LABUH BARU BARAT KECAMATAN PAYUNG SEKAKI PEKANBARU MENGGUNAKAN METODE GEOLISTRIK KONFIGURASI SCHLUMBERGER
}

\author{
Krisman", Citra Siti Fatimah Julianti, Juandi M \\ Program Studi S1 Fisika FMIPA, Universitas Riau \\ *E-mail korespondensi : krisman.sabar@gmail.com; citrasiti7@gmail.com
}

\begin{abstract}
Underground water is one of the important component sources for human being. Study on interpretation of underground water flow has been carried out using Geoelectric Schlumberger Electrode Configuration in Labuh Baru Barat Village, Payung Sekaki District, Pekanbaru. The range measurement was chosen to be 240 meter. The output of measurement arecurrent and voltage. The data, then was inputed into software progress and surfer 11. The output of this computer program is a map of underground waterflow pettern and underground lithology. The results of mapping of the pattern of underground water flow indicate that the direction of water flow from North to South direction, or from Pinang street to Payung Sekaki street. The thickness of the layer start from the first layer that is 4.05 meters and 5.4 meters is a layer of silt- clay, the second layer is 13.07 meters and 14.3 meters is a layer of mud stone, the third layer is 13.07 meters and 15.2 meters is a layer of sand and alluvial and the fourth layer is 51.1 meters and 79.2 meters is layer of gravel sand.
\end{abstract}

Keywords : Flow pattern, groundwater, geolistrik method, Schlumberger configuration

\begin{abstract}
ABSTRAK
Air bawah tanah adalah salah satu sumber komponen penting bagi manusia.Telah dilakukan analisa interpretasi pola aliran air bawah tanah dibuat menggunakan data pengukuran geolistrik konfigurasi elektroda Schlumberger di Kelurahan Labuh Baru Barat Kecamatan Payung Sekaki Pekanbaru.Pada penelitian ini, pengukuran menggunakan bentangan 240 meter. Keluaran dari pengukuran berupa nilai arus dan tegangan. Data tersebut, kemudian dimasukkan ke dalam software progress dan surfer 11. Hasil yang diperoleh dari program computerini adalah peta pola aliran air bawah tanah dan litologi lapisan bawah tanah. Hasil pemetaan pola aliran air bawah tanah menunjukkan bahwa arah aliran air dari Utara ke Selatan, yaitu dari Jalan Pinang ke Jalan Payung Sekaki. Ketebalan lapisan mulai dari lapisan pertama 4,05 meter dan 5,4 meter merupakan lapisan silt-lempung, lapisan ke dua 13,07 meter dan 14,3 meter merupakan lapisan batu lumpur, lapisan ke tiga 13,07 meter dan 15,2 meter merupakan lapisan pasir dan alluvial dan lapisan ke empat 51,1 meter dan 79,2 meter merupakan lapisan pasir kerikil.
\end{abstract}

Kata kunci :Pola aliran, air tanah, metode geolistrik, konfigurasi Schlumberger

\section{PENDAHULUAN}

Air merupakan komponen penting bagi kehidupan makhluk hidup di Bumi.Semakin meningkatnya jumlah makhluk hidup maka semakin meningkat kebutuhan air yang diperlukan, sehingga perlu dijaga keberlanjutan akuifer bebas yang mempertimbangkan faktor imbuhan[1]. Beberapa faktor yang harus diperhatikan adalah factor litologi dan ketebalan aquifer[2].

Sumur cincin merupakan salah satu sumber yang dapat digunakan untuk mendapatkan
air.Sumur cincin banyak digunakan oleh masyarakat karena pembuatannya relatif mudah karena menggunakan peralatan yang sangat sederhana dan harga yang murah[3]. Kelurahan Labuh Baru Barat Kecamatan Payung Sekaki Pekanbaru merupakan salah satu daerah yang masyarakatnya masih banyak menggunakan sumur cincin. Sumur cincin yang berada pada daerah ini memiliki air yang tidak layak dikonsumsi karena airnya memiliki warna yang tidak jernih atau kekuningkuningan sehingga apabila digunakan untuk mencuci pakaian akan berubah menjadi 
kekuning-kuningan, begitu pula apabila ditampung di bak mandi akan menghasilkan endapan serta warna kekuning-kuningan pada bak mandi.Air tanah sebagai salah satu bagian dari sumber daya air merupakan yang paling diminati oleh manusia.Air tanah berasal dari suatu formasi geologi yang dapat menyimpan dan meluluskan air dalam jumlah besar yang dikenal sebagai akuifer[4].Salah satu keuntungan yang diperoleh dalam menggunakan air tanah sebagai sumber kebutuhan yaitu variasi kualitas air tanah dari waktu ke waktu relatif stabil[5].

Metode yang dapat dilakukan untuk pemetaan air bawah tanah adalah metode geolistrik, yaitu berdasarkan nilai resistivitas yang didapat, maka diinterpretasikan air tanah yang ada di suatu daerah.Beberapa metode penyelidikan permukaan tanah yang dapat dilakukan, diantaranya: metode geologi, metode gravitasi, metode magnit, metode seismik, dan metode geolistrik. Dari metodemetode tersebut, metode geolistrik merupakan metode yang banyak sekali digunakan dan hasilnya cukup baik[6].

Penelitian ini dapat memberikan solusi kepada warga di Kelurahan Labuh Baru Barat Kecamatan Payung Sekaki Pekanbaru ini dalam hal tindakan untuk mengetahui pola penyebaran air bawah tanah melalui hasil pemetaan dapat diketahui daerah mana yang rawan pencemaran dan banjir dapat ditentukan.

\section{TINJAUAN PUSTAKA}

\section{Lokasi Penelitian}

Kelurahan Labuh Baru Barat Kecamatan Payung Sekaki Kota Pekanbaru, merupakan salah satu Kecamatan di kota Pekanbaru yang bertopografi dataran. Kelurahan Labuh Baru Barat Kecamatan Payung Sekaki Kota Pekanbaru. Batas-batas wilayah Kecamatan Payung Sekaki adalah:

a. Sebelah timur:Kecamatan Sukajadi dan Kecamatan Sinapelan,

b. Sebelah barat :Kabupaten Kampar, c. Sebelah utara :Kecamatan Rumbai,

d. Sebelah selatan :KecamatanTampan danKecamatan Marpoyan Damai.

Kecamatan Payung Sekaki merupakan salah satu Kecamatan di wilayah Kota Pekanbaru, terdiri atas $39 \mathrm{RW}$ dan 181RT. Luas wilayah Kecamatan Payung Sekaki adalah 51,36 $\mathrm{km}^{2}[7]$.

\section{Air Tanah}

Air tanah (groundwater) berbeda dengan air dalam tanah (soil water). Air tanah (groundwater) merupakan air yang berada pada lapisan akuifer atau zona jenuh air (saturated zona). Sedangkan air dalam tanah (soil water) adalah air yang berada pada zona tidak jenuh air (unsaturated zona)[8].Lapisan yang dapat dilalui dengan mudah oleh air tanah seperti pasir atau kerikil disebut lapisan permeable. Lapisan yang sulit dilalui air tanah seperti lempung atau lapisan silt disebut sebagai aquicludei, dan lapisan yang menahan air seperti lapisan batuan (rock) disebut dengan lapisan aqifuge. Kedua lapisan ini merupakan lapisan impermeable[9].

\section{Metode Geolistrik Konfigurasi Schlumberger}

Metode geolistrik ialah salah satu metode dalam geofisika yang mempelajari sifat aliran listrik di dalam Bumi dan bagaimana cara mendeteksinya di permukaan Bumi. Metode geolistrik tahanan jenis konfigurasi Schlumberger banyak digunakan dalam pengukuran tahanan jenis Bumi.Aliran arus listrik dalam mengalir di dalam tanah melalui batuan-batuan dan sangat dipengaruhi dengan adanya air tanah. Metode geolistrik tahanan jenis lebih efektif jika digunakan untuk eksplorasi yang sifatnya dangkal, karena jarang memberikan informasi lapisan di kedalaman lebih dari 300-400 meter.

Prinsip kerja dari metode geolistrik adalah mengalirkan arus listrik ke dalam Bumi melalui dua elektroda arus dan elektroda potensial, sehingga nilai resistivitasnya dapat dihitung. Berdasarkan Hukum Ohm, dapat 
diketahui bahwa besar tegangan suatu material bergantung pada kuat arus dan hambatan listrik yang dapat dirumuskan sebagai berikut:

$$
V=I
$$

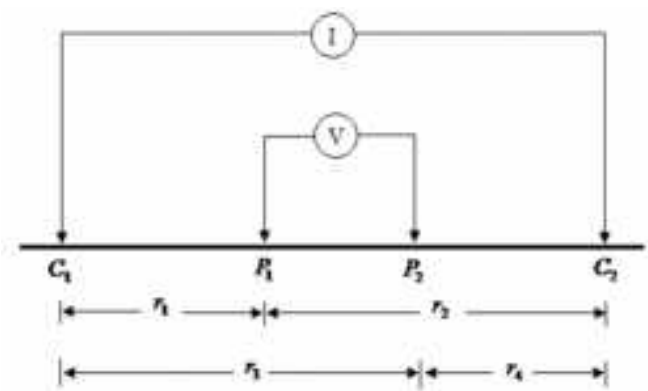

Gambar 1. Dua pasang elektroda arus dan potensial pada permukaan medium homogen isotropis dengan tahanan jenis $\rho[10]$.

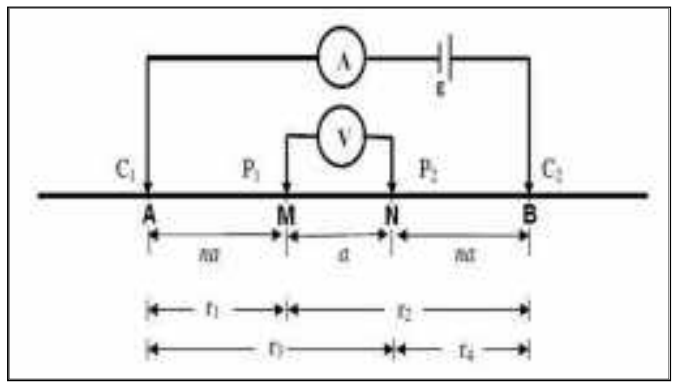

Gambar 2. Metode geolistrik konfigurasi schlumberger

Potensial pada titik P1 akibat elektroda arus C1 adalah:

$V_{1}=\left(\frac{l}{2 \pi}\right) \frac{1}{r_{1}}$

$V_{1}=-\left(\frac{l_{1}}{2 \pi}\right) \frac{1}{r_{i}}$

$\Delta P_{1}=V_{1}+V_{1}=\frac{l}{2 \pi}\left(\frac{1}{r_{1}}-\frac{1}{r_{2}}\right)$

Dengan cara yang sama, potensial untuk elektroda $P_{2}$ akibat arus $C_{1}$ dan $C_{2}$ adalah:

$\Delta Y_{2}=V_{2}+V_{2}=\frac{l}{2 \pi}\left(\frac{1}{r_{a}}-\frac{1}{r_{4}}\right)$

Sehingga beda potensial antara $H_{1}$ dan $H_{2}$ dapat ditulis sebagai berikut:

$\Delta V=\frac{l}{2 \pi}\left\{\left(\frac{1}{r_{1}}-\frac{1}{r_{i}}\right)-\left(\frac{1}{r_{1}}-\frac{1}{r_{4}}\right)\right\}$

$\Delta V=\frac{l}{2 \pi}\left(\frac{1}{r_{1}}-\frac{1}{r_{i}}-\frac{1}{r_{a}}+\frac{1}{r_{4}}\right)$

Konfigurasi Schlumberger ini memiliki empat elektroda yang ditempatkan dalam satu garis lurus, dengan elektroda arus sebelah luar elektroda potensial. Pada susunan elektroda Schlumberger ini, elektroda arus listrik mempunyai jarak yang jauh lebih besar dibandingkan dengan jarak elektroda potensial, dimana jarak elektroda arus lebih besar sama dengan lima kali jarak elektroda potensial., seperti pada Gambar 2.

Harga faktor geome(2i4亿k) didapat dengan memperhatikan gambar elektroda $\mathrm{AB}$ akan bergerak keluar untuk suatu jarak MN tertentu. Faktor geometri didapat dengan perbandingan AB dan MN. Berdasarkan Hukum Ohm, maka rumus dapat diturunkan sebagai berikut:

$$
\begin{aligned}
& \rho=k \frac{\Delta V}{l} \\
& k=\frac{l}{\Delta V}
\end{aligned}
$$

Masukan nilai dari $\Delta V$ dari persamaan (6), yaitu:

$$
\begin{aligned}
& k=\frac{l}{\frac{1}{2 \pi}\left(\frac{1}{r_{1}}-\frac{1}{r_{2}}-\frac{1}{r_{a}}+\frac{1}{r_{4}}\right)} \\
& k=\frac{2 \pi}{\left(\frac{1}{r_{1}}-\frac{1}{r_{2}}-\frac{1}{r_{a}}+\frac{1}{r_{4}}\right)} \\
& k=\frac{2 \pi}{\left(\frac{1}{A}-\frac{1}{\Delta}-\frac{1}{A}+\frac{1}{b}\right)}
\end{aligned}
$$

Berdasarkan Gambar 2 dapat dikatakan bahwa $r_{1}=r_{4}$ dan $r_{4}=r_{3}$ sehingga dengan melihat persamaan (11) maka $r_{1}=A, r_{2}=$ $B \quad, r_{3}=A \quad$ dan $r_{4}=B$.

$A=\frac{A-M}{2}$

$B=\frac{A+M}{2}$

Persamaan (11) dapat ditulis sebagai berikut:

$$
\begin{aligned}
& k=\frac{2 \pi}{\left(\frac{2}{A-M}-\frac{2}{A+M}-\frac{2}{A+M}+\frac{2}{A-M}\right)} \\
& k=\frac{\frac{2 \pi}{4}}{\frac{4}{A-M}-\frac{4}{A+M}} \\
& k=\frac{\frac{2 \pi}{4(A+M)-4(A-M)}}{A-M} \\
& k=\frac{2 \pi\left(A-M{ }^{2}\right)}{4\{(A-M)+(A+M)\}}(17)
\end{aligned}
$$$$
\text { Berdasarkan persamaan (17), maka }
$$
faktor geometri data dirumuskan sebagai berikut:

$k=\frac{\pi\left(A^{2}-M^{2}\right)}{4 M}$

\section{Litologi}

Litologi adalah deskripsi batuan pada singkapan berdasarkan karakteristik, seperti: warna, komposisi mineral dan ukuran butir sinonim dengan Petrografi. Litologi suatu daerah mempunyai ciri-ciri yang berbeda. 
Litologi merupakan sifat atau ciri batuan yang terdiri dari struktur komposisi mineral dan tata letak bahan-bahan pembentuknya yang dipengaruhi oleh proses sedimentasi dan pelapukan. Litologi juga merupakan dasar penuntun hubungan dari susunan perlapisan batuan yang telah dikenal. Litologi suatu batuan memberikan acuan tentang mineraloginya, tekstur, kemas yang mengarahkan kepada klasifikasi yang dapat diterima[11].

\section{Kontur}

Salah satu unsur yang penting pada suatu peta topografi adalah informasi tentang tinggi suatu tempat terhadap rujukan tertentu.Untuk menyajikan variasi ketinggian suatu tempat pada peta topografi, umumnya digunakan garis kontur (contour-line). Garis kontur adalah garis yang menghubungkan titik-titik dengan ketinggian sama[12].

\section{METODE PENELITIAN}

Penelitian ini menggunakan metode eksperimen lapangan, proses pengukuran lapangan untuk mendapatkan data koordinat lokasi yang lebih spesifik menggunakanGPS dan pengambilan data geolistrik menggunakan resistivitymeter.

Data yang dikumpulkan akan diproses menggunakan software progress dan surfer 11 untuk menentukan litologi lapisan dan membuat peta kontur polaaliran air bawah tanah di Kelurahan Labuh Baru BaratKecamatan Payung Sekaki di Laboratorium Fisika Bumi Jurusan Fisika FMIPA Universitas Riau.Langkah-langkah pengambilan data geolistrik adalah sebagai berikut:

1. Mengukur panjang lintasan yang akan diteliti.

2. Menentukan titik tengah dari panjang lintasan sebagai titik acuan dimulai pengukuran.

3. Menghubungkan kabel-kabel pada elektroda arus dan elektroda potensial dan menghubungkannya ke alat resistivity meter.

4. Menancapkan elektroda arus dan elektroda potensial di tanah dengan kedalaman 15 $\mathrm{cm}$.

5. Mengatur jarak elektroda yakni jarak elektroda potensial (MN) 2 meter dan jarak elektroda arus (AB) adalah 6 meter.

6. Hubungkan alat resistivity meter ke accu, kemudian catat hasil awal Pindahkan masing-masing elektroda arus sejauh 2 meter dan masing-masing elektroda potensial sejauh 1 meter sampai dengan panjang lintasan yang diukur habis.

7. Lakukan pengambilan data di titik selanjutnya dengan langkah yang sama pada titik pertama dengan mengatur spasi antara elekroda arus dan elektroda potensial.

Hasil pengukuran yang didapatkan dari lokasi penelitian berupa data resistivitas yang diolah dengan menggunakan software Progress. Data resistivitas terlebih dahulu dihitung nilai resistivitasnya (7), kemudian nilai faktor geometrinya dihitung dengan menggunakan persamaan (18). Membuat model resistivitaslapisan bawah tanah dapat dibuat dengan melihat litologi-litologi yang sama disetiap lapisan pada lokasi penelitian. Kemudian setiap lapisan yang memiliki litologi yang sama akan dihubungkan sehingga akan diperoleh model resistivitas lapisan bawah tanahnya. Menggunakan software surfer 11 untuk menentukan pola aliran air bawah tanah di lokasi penelitian.

\section{HASIL DAN PEMBAHASAN}

\section{Hasil Pengukuran DanPengolahan Data Geolistrik}

Hasil pengukuran data geolistrik yang dilakukan di Kelurahan Labuh Baru Barat Kecamatan Payung Sekaki Kota Pekanbaru di dua titik pengukuran yaitu Jalan Pinang dan Jalan Payung Sekaki menggunakan konfigurasi Schlumberger, menghasilkan nilai beda potensial $(\Delta \mathrm{V})$ dan arus listrik (I), 
sehingga nilai resistivitas dapat dihitung. Hasil dari pengolahan data resistivitas semu didapat menggunakan program software progress untuk memperoleh nilai resistivitas sebenarnya. Hasil yang didapat dari software ini menunjukkan litologi lapisan-lapisan bawah tanah dan jenis yang terdapat pada lapisan tersebut.

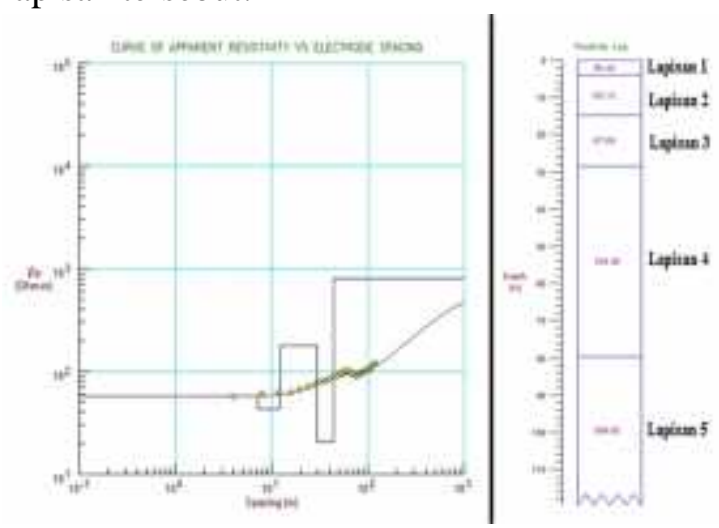

Gambar 3. Grafik interpretasi geolistrik pada Jalan Pinang

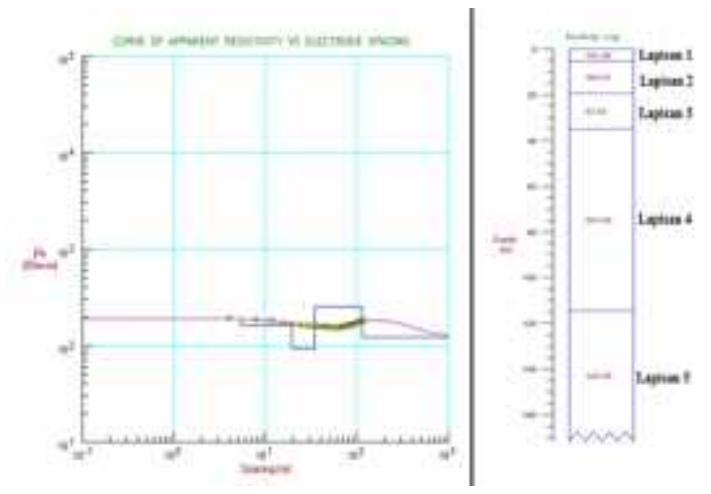

Gambar 4. Grafik interpretasi geolistrik pada Jalan Payung Sekaki

Berdasarkan hasil pengolahan data pada Gambar 3menunjukan struktur lapisan tanah lokasi penelitian di Jalan Pinang yang terdiri dari lima lapisan. Penamaan atau jenis masingmasing lapisan dapat diinterpretasikan dari nilai resistivitas yang didapat dari pengolahan data. Lapisan pertama dengan nilai resistivitas $56,40 \Omega \mathrm{m}$ dengan ketebalan lapisan tanah 4,05 meter diinterpretasikan sebagai lapisan siltlempung. Lapisan kedua dengan nilai resitivitas $62,13 \Omega \mathrm{m}$ dengan ketebalan lapisan tanah 10 meter diinterpretasikan sebagai lapisan batu lumpur. Lapisan ketiga dengan nilai resistivitas $67,09 \Omega \mathrm{m}$ dengan ketebalan lapisan tanah 13,07 meter diinterpretasikan dengan lapisan aluvium dan pasir. Lapisan keempat dengan nilai resistivitas $109,36 \Omega \mathrm{m}$ dengan ketebalan lapisan tanah 51,1 meter diinterpretasikan sebagai lapisan pasir kerikil. Lapisan kelima dengan nilai resistivitas $399,85 \Omega \mathrm{m}$ dengan ketebalan lapisan tanpa batas yang diinterpretasikan sebagai lapisan pasir kerikil kelanauan.

Berdasarkan hasil pengolahan data pada Gambar 4 menunjukan struktur lapisan tanah lokasi penelitian di Jalan Payung Sekaki yang terdiri dari lima lapisan. Lapisan pertama dengan nilai resistivitas 191,06 $\Omega \mathrm{m}$ dengan ketebalan lapisan tanah 5,4 meter yang diinterpretasikan sebagai lapisan silt-lempung. Lapisan kedua dengan nilai resistivitas $164,47 \Omega \mathrm{m}$ dengan ketebalan lapisan tanah adalah 14,1 meter yang diinterpretasikan sebagai lapisan batu lumpur. Lapisan ketiga dengan nilai resistivitas $93,50 \Omega \mathrm{m}$ dengan ketebalan lapisan tanah adalah 15,2 meter yang diinterpretasikan sebagai lapisan alluvial dan pasir. Lapisan keempat dengan nilai resistivitas 254,46 $\Omega \mathrm{m}$ dengan ketebalan lapisan tanah adalah 79,2 meter yang diinterpretasikan sebagai lapisan pasir kerikil. Lapisan terakhir diinterpretasikan sebagai lapisan pasir kerikil kelanauan dengan nilai resistivitas $122,58 \Omega \mathrm{m}$.

\section{Hasil Pemetaan Pola AliranAir Bawah Tanah}

Hasil pengolahan data yang didapat dengan menggunakan softwere progress kemudian diolah dengan menggunakan software surfer 11 untuk mengetahui pola aliran air tanah dengan memasukkan nilai koordinat lintang pada sumbu $\mathrm{X}$, bujur sebagai sumbu $\mathrm{Y}$ dan data ketebalan lapisan sebagai sumbu $\mathrm{Z}$. Interpretasi pola aliran air tanah pada setiap lapisan ditunjukkan pada Gambar 5.

Berdasarkan hasil pametaan pola aliran air bawah tanah dengan menggunakan software surfer 11 yang dibuat berdasarkan ketebalan dari setiap lapisan yang ditunjukan dari Jalan Pinang dan Jalan Payung Sekaki dapat 
dianalisa pola aliran air tanah mengalir dari Utara ke Selatan sesuai Gambar 5.

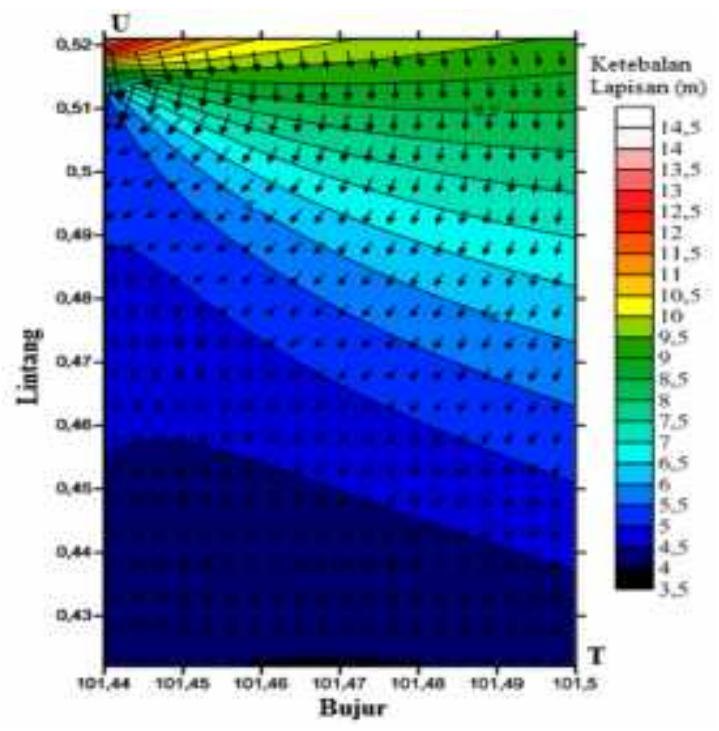

Gambar 5. Peta kontur pada lapisan di Jalan Pinang dan Jalan Payung Sekaki

\section{KESIMPULAN DAN SARAN}

\section{Kesimpulan}

Berdasarkan hasil penelitian dengan menggunakan metode geolistrik konfigurasi elektroda Schlumberger pada dua titik lokasi di Kelurahan Labuh Baru Barat Kecamatan Payung Sekaki Kota Pekanbaru yaitu di Jalan Pinang dan Jalan Payung Sekaki, kemudian data diolah menggunakan software progress dan software Surfer 11, maka didapatkan beberapa kesimpulan sebagai berikut:

1. Pola aliran air tanah yang terbentuk dari hasil pengolahan data software progress dan software Surfer 11 terlihat arah aliran air tanah yang mengikuti bentuk aliran dari lapisan tanah yang terbentuk dari lima lapisa dengan arah alirannya adalah dari arah Utara ke Selatan dengan titik lokasinya adalah Jalan Pinang ke Jalan Payung Sekaki.

2. Hasil pengolahan data software progress dapat terinterpretasikan jenis lapisan tanah, dan pengolahan data software surfer 11 dapat menginterpretasikan pola aliran air bawah tanah di dua titik penelitian di
Kelurahan Labuh Baru Barat Kecamatan Payung Sekaki Pekanbaru.

3. Hasil pengolahan data di Jalan Pinang dan Jalan Payung Sekaki Kelurahan Labuh Baru Barat Kecamatan Payung Sekaki Pekanbaru masing-masing terdiri dari lima lapisan dengan litologi, ketebalan dan resitivitas yang berbeda. Lapisan pertama dengan ketebalan 4,05 meter dan 5,4 meter dengan nilai resistivitas $56,40 \Omega \mathrm{m}$ dan 191,06 $\Omega m$ merupakan lapisan siltlempung, lapisan ke dua dengan ketebalan 13,07 meter dan 14,3 meter dan nilai resistivitas $62,13 \Omega m$ dan $164,47 \Omega m$ merupakan lapisan batu lumpur, lapisan ke tiga dengan ketebalan 13,07 meter dan 15,2 meter dan nilai resistivitas $67,09 \Omega \mathrm{m}$ dan 93,50 $\Omega m$ merupakan lapisan pasir dan alluvial dan lapisan ke empat dengan ketebalan 51,1 meter dan 79,2 meter dengan nilai resistivitas $109,36 \Omega m$ dan 254,46 $\Omega \mathrm{m}$ merupakan lapisan pasir keriki, pada lapisan ke lima yang ke tebalannya tidak dapat terukur oleh alat memiliki nilai resistivitas $339,85 \Omega m$ dan 122,58 $\Omega m$ merupakan lapisan pasir kerikil kelanauan. Nilai resistivitas terkecil di Jalan Pinang terdapat pada lapisan pertama yaitu 56,40 $\Omega m$ dengan ketebalan 4,05 meter, sedangkan nilai resistivitas terbesar di Jalan Pinang terdapat pada lapisan ke lima yaitu $399,85 \Omega m$ dengan ketebalan yang tidak terjangkau oleh alat ukur. Nilai resistivitas terkecil di Jalan Payung Sekaki terdapat pada lapisan ke tiga yaitu $93,50 \Omega m$ dengan ketebalan 15,2 meter, sedangkan nilai resistivitas terbesar terdapat pada lapisan ke empat dengan nilai $254,46 \Omega m$ dengan kedalaman 79,2 meter.

4. Pengamatan yang dilakukan pada kondisi air sumur disekitar Kelurahan Labuh Baru Barat Kecamatan Payung Sekaki Kota Pekanbaru ini memiliki kondisi air tercemar yang layak pakai atau masih memiliki nilai guna oleh warga setempat sebagai MCK (Mandi, Cuci, dan Kakus), 
karena air hanya memiliki bau yang tidak sedap atau bau yang menyengat.

\section{Saran}

Berdasarkan hasil analisis yang dilakukan dalam penelitian ini dan merupakan tahap awal dari praduga dan memberikan informasi tentang litologi dan pola aliran air bawah tanah di Kelurahan Labuh Baru Barat maka dapat ditulis saran untuk tahap selanjutnya, yaitu:

1. Perlu adanya penambahan titik dan pengulangan pengukuran elevasi dikawasan tersebut, karena semakin banyak sampel dan data elevasi yang diteliti maka semakin akurat data yang didapatkan.

2. Penentuan pola aliran air tanah yang dilakukan menggunakan metode geolistrik konfigurasi Schlumberger merupakan tahap awal untuk memberikan informasi bagaimana gambaran pola aliran air di permukaan tanah.

\section{UCAPAN TERIMA KASIH}

Penulis mengucapkan terima kasih kepada Bapak Dr. Juandi M, M.Si., Drs. Krisman, M.Si. yang berkenan membimbing serta memberikan sumbangan pola pikir, waktu dan motivasi sehingga penulis dapat menyelesaikan karya ilmiah ini.

\section{DAFTAR PUSTAKA}

1. Juandi, M. (2015). Faktor imbuhan untuk keberlanjutan akuifer bebas.Prosiding SEMIRATA Bidang MIPA, Universitas Tanjungpura Pontianak, 5-7 Mei 2015, 319-325.

2. Ahmad, A. (2014). Analisis parameter akuifer bebas kota pekanbaru untuk keberlanjutan air bawah tanah. Jurnal Ilmu Lingkungan, 7(2): 148-158.
3. Kemenkes. (2014). Riskesdas Badan Penelitian dan Pengembangan Kesehatan Departemen Kesehatan Re-publik Indonesia. Jakarta.

4. Purnama. (2000). Bahan Ajar Geohidrologi. Yogyakarta:Fakultas Geografi Universitas Gadjah Mada.

5. Sudarmadji, S. (1997). Prosedur Analisa untuk Bahan Makanan dan Pertanian.Yogyakarta:Liberti.

6. Hardy, S. J. \& Goodman, R. E. (2005). "Web resources in the history of geophysics". American Geophysical Union.Archived from the original on 27 April 2013. Retrieved September 2011.

7. Badan Pusat Statistik Kota Pekanbaru. (2016). Kecamatan payung Sekaki dalam Angka 2016. ISBN 979-484-653-8. Pekanbaru : Kota Pekanbaru.

8. Todd, D. K. (1980). Groundwater Hydrology. New York: Jhon Wiley \& Sons.

9. Kruseman, G. P. \& de Ridder, N. A. (1991). Analysis and Evaluation of Pumping Test Data. $2^{\text {nd }}$ Edition. ILRI: Wageningen.

10. Bahri. (2005). Hand Out MataKuliah Geofisika Lingkungan dengan topik Metoda Geolistrik Resistivitas, Fakultas Matematika dan Ilmu Pengetahuan Alam ITS, Surabaya.

11. Sunarto. (2000). Geologi Dasar 1. Fakultas Geologi. Yogyakarta: Universitas Gadjah Mada.

12. Frick, H. (1991). Mekanika Teknik 1 Statika dan Kegunaan, Yogyakarta: Kanisius. 